\title{
Analysing Enhancement of Electricity Generating Capacity with Solar Tracking System of the Most Sunning Region of Turkey
}

\author{
Kemal Akkılıç, Yusuf Selim Ocak, and Musa Yılmaz
}

\begin{abstract}
Despite the increasingly widespread production of electricity from solar energy and despite Turkey is in the sun belt, Turkey cannot used its potential sufficiently effective and widely. Especially, this situation is of more importance for the Southeastern Anatolia Region Turkey's most sunning area. In this study, among renewable energy resources the generation of electricity from solar energy in terms of both its current potential and production technologies and the solar energy potential of Southeastern Anatolia Region provinces and the degree and method of using this potential to generate electricity have been investigated. Suggestions have been made to benefit from the solar energy in a way of effective and widespread for Southeastern Anatolia Region. Also, a suggestion for convenient place which is $130 \mathrm{~m}^{2}$ and was formed by Karacadağ volcanic eruption and is not used for agriculture and rocky area has been made.
\end{abstract}

Index Terms-Southeastern anatolia region, solar energy, photovoltaic solar tracker.

\section{INTRODUCTION}

Nowadays, the use of alternative energy sources for sustainable development is mandatory for two reasons. First reason is increased energy usage due to declining fossil fuel reserves and the second reason is increasing environmental pollution and damage that is the nature. Among the renewable energy sources, including solar energy inside these opportunities waiting to be developed in the host, source of energy. The potential of solar energy has an opportunity is more easily than other renewable energy sources with ease of use in a way that could spread.

Located in the sun-belt countries like our country to one of the most important alternative energy source is the sun. According to reports, the amount of energy per unit surface area in Daily highest in southeastern Anatolia and the Mediterranean $\left(19 \mathrm{Mj} / \mathrm{m}^{2}\right)$, the lowest in eastern black sea $\left(12 \mathrm{Mj} / \mathrm{m}^{2}\right)$ [1]. The maximum of solar radiation per unit surface area as it can be transform to know how much of the useful work is important design and dimensioning of solar energy .In order to determine the maximum available from the

Manuscript received April 24, 2014; revised July 2, 2014. This project was supported by Dicle Üniversitesi Bilimsel Araştırma Projeleri Koordinatörlüğü (Dicle University of Scientific Research Projects Coordinator), (12-MYO-146).

Kemal Akkılıc and Yusuf Selim Ocak are with Dicle University, Faculty of Ziya Gökalp Education, Physics, Campus, Diyarbakir, Turkey (e-mail: \{kakkilic, selimocak\}@dicle.edu.tr).

Musa Yllmaz is with the Dicle University, Diyarbakir Technical Vocational School, Electrical and Energy Department, Diyarbakir, Turkey (e-mail: musayilmaz72@gmail.com,myilmaz@dicle.edu.tr). solar energy is different approaches available in the litterateur [2].

Solar energy as a renewable energy be converted into useful energy in many countries play a very important role in the energy budget so purpose of this study; southeastern Anatolia region of the solar radiation energy can be converted to electrical energy is examine the part.

\section{SOLAR ENERGY}

Solar energy is inexhaustible, is not to pollute environment and require importing. The advent of energy consumption in the age, primary energy sources are constantly used up, also this source burned. Thus, some problems are revealed such as ecological deteriorations, climatologist balance corruptions. However, there are potential ways to solve these problems. First solution is that new and clean energy sources will be exploring .Second solution is that consumption of energy is reduced economic views. New sources of energy one of the atomic energy, is not provide solution. Because, atomic energy leads to increase environmental health risk by the its reactor and climatologist balance corruptions. The biggest source of fusion energy is the sun. Solar energy is hopeful for primary energy sources such as petrol, coal and atomic energy. Because solar energy does not pollute environment with sun battery and it does not damage the climatologist balance with direct current electricity energy and through transformers is given network directly. In addition, it may transform hydrogen gas and store up. The energy density of the earth from the sun, is per square meter is up to $1,35 \mathrm{Kw}$. This density from around the world the area covered by solar power is in $152424.10^{13} \mathrm{kWh}$, the total power of electric power plants in the world are encrypted 100 thousand times. As seen in Fig. 1. Humanity's energy system from solar power is $9,5.10^{13} \mathrm{kWh}$ power that can be 15 thousand times. All the world's solar energy falling on the surface of one year, $1,22.10^{14}$ TCE (tons of coal equivalent) or $0,814.10^{14} \mathrm{TOE}$ (tons of oil equivalent) is as glorious size. In addition, the solar energy is known reserves of coal a year, 50 times and 800 times as much of the known oil reserves. The intended use of solar energy in the process has been the second half of our century. Today using of solar energy for everyday life from the structure and communication, agriculture, industry sector, power plants, military services and space extends [1], [3].

Nowadays, an application of solar energy is gaining importance; in the almost every country, outside of sunny heats up water heater construction of buildings. Solar water pumps are used in agricultural irrigation. Solar energy is 
converted to electrical. Hydrogen, which fuel of the future of water in the production of solar energy can be listed as.

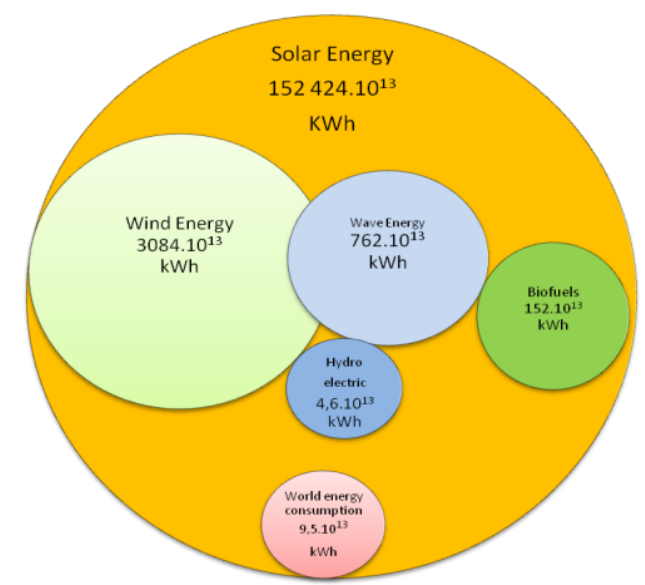

Fig. 1. World energy consumption and production status.

\section{SOLAR CELLS}

Solar cells are semiconductors materials which coming to the surface sunlight converts into electrical energy directly. Their surface is square, rectangle, and circle. Fields of this solar cells are approximately $100 \mathrm{~cm}^{2}$, thicknesses of this solar cells are approximately 0,2-0,4 mm. Solar cells work based on photovoltaic principle so when the light falls on them, electrical voltage occurs in their the ends. Source of electricity energy which given the battery ,coming to the surface solar energy .Solar energy may be converting electricity but it is associate with their constitutions of $\% 5$ and $\% 40$ with efficient. In order to increase of power output, many solar cells are connected in series or in parallel and mounted on the surface. This structure is called solar cell module or photovoltaic module. Thus, system is created a few watt or mega watts [1].

\section{SOlAR TRACKING SYSTEMS}

Solar cells produce electricity energy from sunlight with using photon energy. Thus obtained electrical output is directly proportional with the amount of sunshine. During the day, sun's rays reach earth at different angles. Thus, in order to obtain maximum electricity energy from solar cells, PV systems need to follow the trajectory of the sun. This system is called solar tracking system (STS). Solar tracking systems have got east-west (one-axis) and north-south (two-axis) [4].

Solar tracking system is fixed angle and maintenance costs are higher than other systems. Therefore, this type of system is able to amortize the cost over the long term, durable, low situation of over shading buildings. Solar tracking system should found uptown in order to increase their performance. Thus, sensor and systems related costs will decrease. The battery from the system will be connected ongrid also would eliminate the costs.

\section{TURKEY's SOLAR POTENTIAL}

Unfortunately, our country is dependent on outside. Thus, this situation leads to increase economical and different problems so these problems may solve with alternative energy sources such as wind power and solar energy.

Our country us luckier than other country in having solar energy potential because of geographical position. Turkey's annual energy production is believed to be 230 million MW (2012 TEİAŞ=Turkish Electricity Transmission Company), in a second incoming solar energy to the world. This turkey's energy production is almost 1.000 times. According to Turkish State Meteorological Service, Turkey's average annual total sunshine duration hours is 2640 (daily total of 7,2 hours), average total the radiation intensity is 1311 $\mathrm{kwh} / \mathrm{m}^{2}$-year (day total $3,6 \mathrm{kWh} / \mathrm{m}^{2}$ ). Turkey, have a high potential for solar energy (110 days in year) and Turkey can produce per square meter of solar energy per year in 1100 kWh [3], [5], [6].

TABLE I: TURKEY'S SOLAR ENERGY POTENTIAL OF TOTAL MONTHLY DISTRIBUTION [1], [3]

\begin{tabular}{lllc}
\hline \multicolumn{3}{c}{ Monthly Total Solar Energy } & $\begin{array}{c}\text { Sunshine } \\
\text { Duration } \\
\text { Month }\end{array}$ \\
& $\left(\mathrm{kcal} / \mathrm{cm}^{2}\right.$-mounth) & $\left(\mathrm{kWh} / \mathrm{m}^{2}\right.$-mounth) & 103,0 \\
January & 4,45 & 51,75 & 115,0 \\
February & 5,44 & 63,27 & 165,0 \\
March & 8,31 & 96,65 & 197,0 \\
April & 10,51 & 122,23 & 273,0 \\
May & 13,23 & 153,86 & 325,0 \\
June & 14,51 & 168,75 & 365,0 \\
July & 15,08 & 175,38 & 343,0 \\
August & 13,62 & 158,40 & 280,0 \\
September & 10,60 & 123,28 & 214,0 \\
October & 7,73 & 89,90 & 157,0 \\
November & 5,23 & 60,82 & 103,0 \\
December & 4,03 & 46,87 & 2640 \\
\hline Total & 112,74 & 1311,00 & 7,2 hour/day \\
\hline Average & $308,0 \mathrm{cal} / \mathrm{cm}^{2}$-day & $3,6 \mathrm{kWh} / \mathrm{m}^{2}$-day & \\
\hline \hline
\end{tabular}

Turkey solar energy potential and sunshine duration are given in Table I. Turkey's annual solar radiation map is given Fig. 2. [1].

By the European union candidate countries and PV solar energy potential is detected in the study of the average of turkey is about $1500 \mathrm{kwh} / \mathrm{m}^{2}$, satellite data and geographical situation of Turkey. The amount of solar energy is 977.000TWh which turkey's whole surface is fallen every year so turkey has 80 billion TOE (tons of oil equivalent) theoretical potential for solar energy. This value of primary energy consumption is 4000 times in 2012. (3).

Plant of solar energy is both technically and economically in order to be global radiation must be installed in an area greater than $1650 \mathrm{kwh} / \mathrm{m}^{2}$ per-year.

Also solar thermal power plant to be built in Turkey;

1) Slope of the land in areas that are larger than 3 degrees,

2) With residential area 500 meters of areas in the emergency lane.

3) Roads and railways in the areas within 100 meters with a seat belt.

4) Environmental protection, national parks and natural areas in the areas within 500 meters of safety areas.

5) In the lakes, rivers, dams, and wetlands.

6) Protect forests, reforestation area, private forests, marshes, and swamps, storage is not suitable to be installed in areas [1]. 


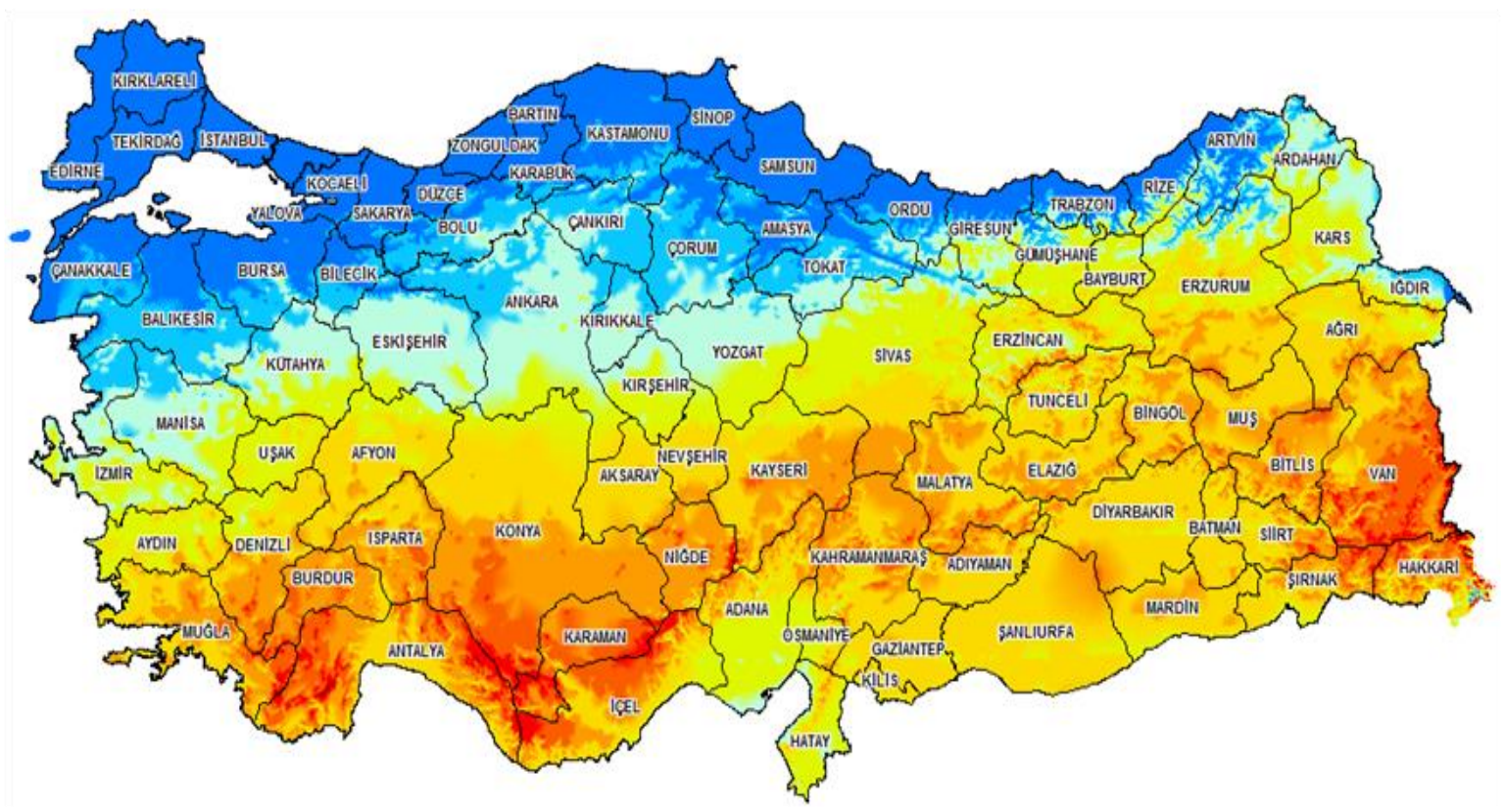

Fig. 2. Map of Turkey's annual solar radiation [1].

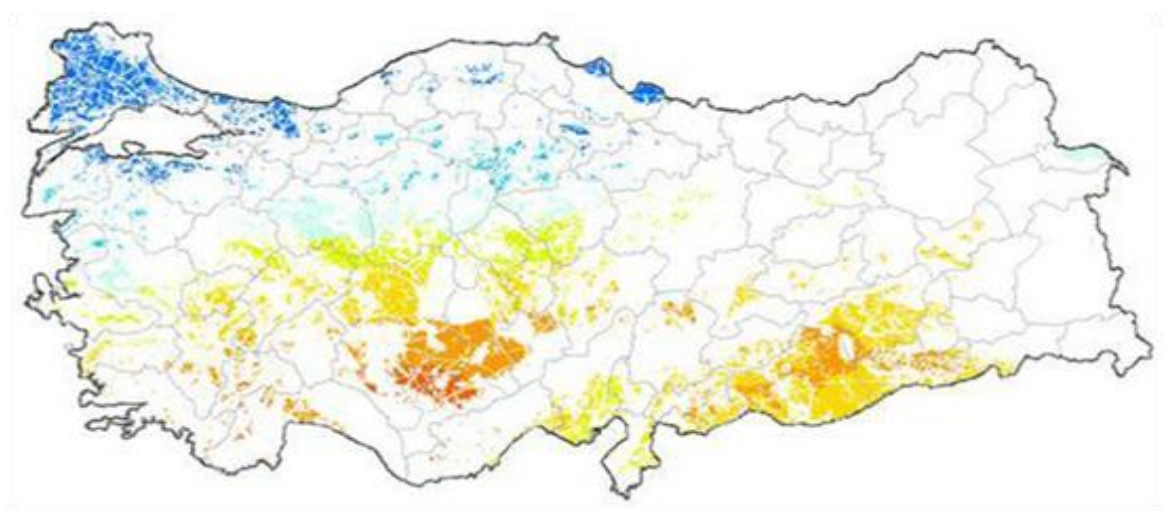

Fig. 3. Power plants of solar thermal can be established field in the Turkey [1].

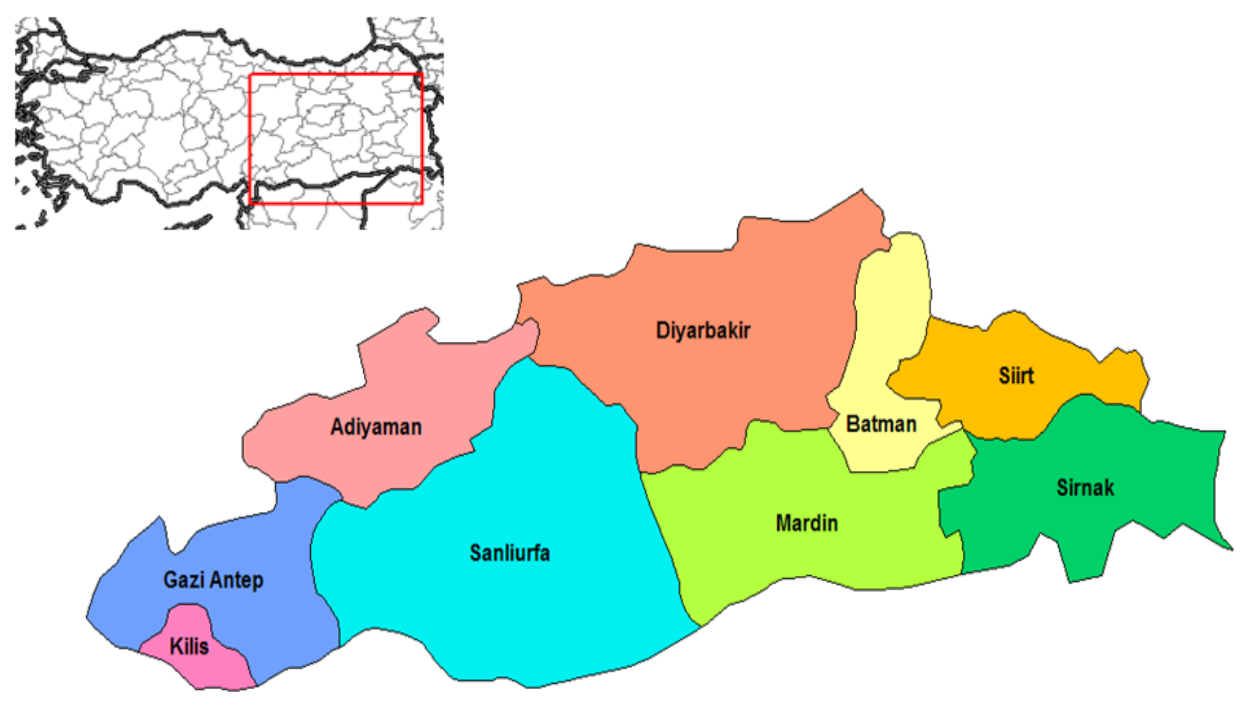

Fig. 4. Southeastern Anatolia region and cities.

\section{SOlar Potential of SOUtheastern ANATOlia REGION}

The richest regions in terms of sunshine hours in Turkey are Southeastern Anatolia Region (Fig. 2 and Fig. 3).This is followed The Mediterranean (2956 hours), Eastern Anatolia (2664 hours), and Marmara (2409 hours) by regions. The minimum value is 1971 hours and the Black Sea Region $1500 \mathrm{kwh} / \mathrm{m}^{2}$ year in our country that are large than average radiation is $4600 \mathrm{~m}^{2}$ three regions. In this areas of solar power plants are \%25. However according to EIE (General Directorate of Renewable Energy), last years the average $\% 20 \% 25$ higher than this value [1].

Southeastern Anatolia $57.000 \mathrm{~km}^{2}$ area is a region of 
Turkey with the smallest surface area (Fig. 4). According to the European Commission Institute for Energy and Transport (IET) Photovoltaic Geographical Information System (PVGIS) provides a map-based inventory of solar energy resource also in this area would be of $1 \mathrm{~m}^{2} 1800 \mathrm{kWh}$ radiation and $1350 \mathrm{kWh}$ production. In $57.000 \mathrm{~km}^{2}$ area in the emission amount can be obtained with the quantity of electricity is 330 times of the production Turkey. So only $170 \mathrm{~km}^{2}$ of southeastern Anatolia region's solar plant to be installed in an area that meets all of Turkey's electrical energy. Only Karacadağ that extinguished volcano which has spread volcanic eruption of lava build up to the rocky area is even enough.

\begin{tabular}{ccc} 
TABLE II: REGIONAL SOLAR ENERGY POTENTIAL OF TURKEY [1], [3] \\
\hline \hline Region & $\begin{array}{c}\text { Total average solar } \\
\text { radiation kWh/m2-year }\end{array}$ & $\begin{array}{c}\text { Average sunshine } \\
\text { duration } \\
\text { h/year }\end{array}$ \\
\hline $\begin{array}{c}\text { Southeastern } \\
\text { Anatolia } \\
\text { Mediterranean }\end{array}$ & 1.460 & 2.993 \\
East Anatolia & 1.390 & 2.956 \\
Central Anatolia & 1.365 & 2.664 \\
Aegean & 1.314 & 2.628 \\
Marmara & 1.304 & 2.738 \\
Black Sea & 1.168 & 2.409 \\
\hline \hline
\end{tabular}

\section{SUNSHINE DURATION OF REGION}

Southeastern Anatolia Region and the city is on the average of Turkey (7.2 hours) and seen in Table II. Solar energy investments are expensive, even for a minute while the sun is quite valuable. Therefore, a gain of $\% 5.83$ per cent is 7.62 per hour. In this big-budget investment is very important. In addition, the amount of radiation in the region because it is more (Turkey's average $1311 \mathrm{kWh} / \mathrm{m} 2$-year). This region on average (1460 $\mathrm{kWh} / \mathrm{m} 2$-year) $\% 11.37$ percent gain is more Turkey's average.

TABLE III: Average Sunshine DuRATION OF SOUTHEASTERn ANATOLIA CiTIES (H) [1]

\begin{tabular}{|c|c|c|c|c|c|c|c|c|c|c|c|c|c|}
\hline \multirow[b]{2}{*}{ Cities } & \multicolumn{13}{|c|}{ MONTHLY } \\
\hline & $\mathbf{J}$ & $\mathbf{F}$ & M & A & M & $\mathbf{J}$ & $\mathbf{J}$ & $\mathbf{A}$ & $\mathbf{S}$ & O & $\mathbf{N}$ & D & Av. \\
\hline Adiyaman & 4.1 & 4.4 & 6.6 & 7.2 & 9.5 & 12.1 & 12.3 & 11.5 & 10.1 & 7.3 & 5.4 & 4.1 & 7.88 \\
\hline Batman & 3.2 & 4.2 & 5.4 & 7.1 & 9.3 & 11.5 & 12.1 & 11.3 & 10 & 7 & 5.2 & 3 & 7.44 \\
\hline Diyarbakır & 3.6 & 4.5 & 5.4 & 6.6 & 9.4 & 12.1 & 12.3 & 11.4 & 9.6 & 7.2 & 5.2 & 3.5 & 7.57 \\
\hline Gaziantep & 3.5 & 4.3 & 5.3 & 6.5 & 8.4 & 10.3 & 10.5 & 10.1 & 8.6 & 7.1 & 5.3 & 3.5 & 6.95 \\
\hline Kilis & 4.1 & 4.6 & 6.2 & 7.4 & 9.2 & 11.2 & 11.4 & 11.1 & 10.6 & 7.3 & 5.4 & 3.6 & 7.68 \\
\hline Mardin & 4.3 & 5 & 6.1 & 7.2 & 10.6 & 12.3 & 12.4 & 11.5 & 10.2 & 7.4 & 5.5 & 4.3 & 8.07 \\
\hline Siirt & 3.4 & 4.3 & 5.4 & 6.3 & 9.1 & 11.5 & 12.2 & 11.3 & 10.1 & 7.2 & 5.1 & 3.3 & 7.43 \\
\hline Şanlıurfa & 4 & 4.5 & 6.1 & 7.3 & 10.6 & 12.1 & 12.1 & 11.2 & 10.6 & 7.4 & 5.5 & 4 & 7.95 \\
\hline Şırnak & 4.5 & 4.3 & 7.5 & 5.4 & 9.3 & 11.1 & 11.2 & 12.1 & 10.3 & 7.2 & 4.6 & 4.3 & 7.65 \\
\hline
\end{tabular}

According state meteorological in between the years 1970-2011 average sunshine duration is Turkey's most sunning area. Most of the region in the province of Mardin and Şanliurfa (Table III). In Fig. 2, Fig. 3, and Fig. 5 of the region provinces map solar radiation and global radiation values by month $\left(\mathrm{kwh} / \mathrm{m}^{2}\right.$-day) is a high potential in all province looking observed. As a result of this study, Table IV and Fig. 5 show solar energy potential of cities of South East Anatolia Region in Turkey as fixed and tracking system.

TABLE IV: PVGIS DATA FIXED AND SOLAR TRACKING SYSTEM FOR SOUTHEASTERN ANATOLIA PROVINCE COMPARISON CHART [7], [8]

\begin{tabular}{lccc}
\hline \hline Cities & $\begin{array}{c}\text { Fixed Systems } \\
\text { Total solar } \\
\text { radiation } \mathrm{kWh} / \mathrm{m}^{2}\end{array}$ & $\begin{array}{c}\text { Two axis tracker } \\
\text { Systems Total solar } \\
\text { radiation } \mathrm{kWh} / \mathrm{m}^{2}\end{array}$ & $\begin{array}{c}\text { Average } \\
\text { gain } \\
\%\end{array}$ \\
\hline Adiyaman & 1840 & 2410 & 30.15 \\
Batman & 1800 & 2370 & 31.34 \\
Diyarbakır & 1820 & 2420 & 32.59 \\
Gaziantep & 1880 & 2450 & 30.22 \\
Kilis & 1810 & 2370 & 30.60 \\
Mardin & 1840 & 2410 & 29.93 \\
Siirt & 1810 & 2370 & 29.41 \\
Şanliurfa & 1830 & 2410 & 31.85 \\
Şırnak & 1810 & 2270 & 23.53 \\
Toplam & 16440 & 21480 & 29.95 \\
\hline \hline
\end{tabular}

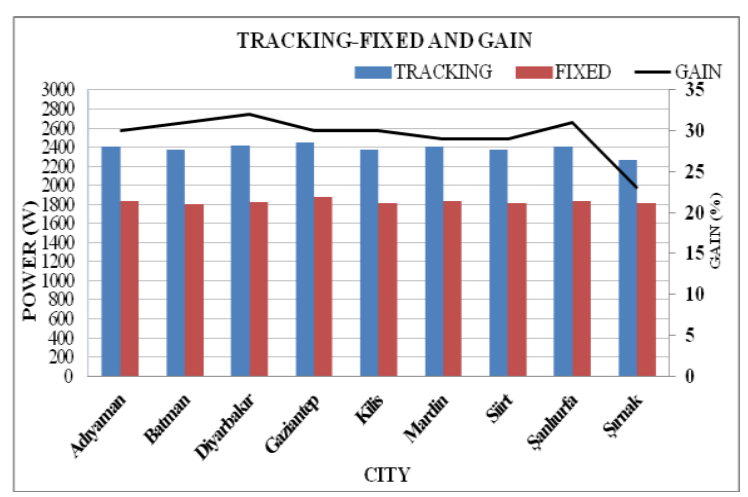

Fig. 5. PVGIS data fixed and solar tracking system for Southeastern Anatolia province comparison graph.

\section{CONCLUSION}

The region and sunshine duration (7.62) and the average global radiation $(1460 \mathrm{kwh} / \mathrm{m} 2$-year) is above the average of Turkey. This difference compared to the average Turkey sunshine duration is $\% 5.83$ the average global radiation in the extra earnings ratio is a $\% 11.37$.

More electricity from solar energy to obtain energy from solar tracking system (STS) is utilized. These systems in obtaining electrical energy from solar radiation according to a fixed system of $\% 5$ to $\% 60$ more efficiency work in the average. According to the European Commission Institute for Energy and Transport (IET) Photovoltaic Geographical Information System (PVGIS) provides a map-based inventory of solar energy resource also in this technology Resource and performance evaluation system of Southeastern Anatolia region and the fixed panel with two-axis solar tracking system in the evaluation of $\% 30$ observed that greater productivity. These system are required by the previously mentioned $170 \mathrm{~km}^{2}$ an area $\left(130 \mathrm{~km}^{2}\right)$ is smaller. On the other hand, accordingly, a lot of space in the Southeastern Anatolia Region is available.

\section{REFERENCES}

[1] EIE. Publication of National Energy Conservation Center. (2012, October). [Online]. Available: http://www.eie.gov.tr. 
[2] M. Öztürk, A. Elbir, and N. Özek, "Akdeniz bölgesine gelen güneş radyasyonunun ekserji analizi," in Proc. 6th International Advanced Technologies Symposium (IATS 'll), Elazı̆̆, Turkey, 16-18 May 2011.

[3] K. B. Varınca and M. T. Gönüllü, "Türkiye'de güneş enerjisi potansiyeli ve bu potansiyelin kullanim derecesi, yöntemi ve yayginliği üzerine bir araştirma," I. Ulusal Güneş Ve Hidrojen Enerjisi Kongresi, Eskişehir, Türkiye, 2006.

[4] F. Kentli and M. Y1lmaz, "Obtaining the optimum efficiency electrical energy under diyarbakir conditions using solar tracking system involving PV panel," EEST Part A, vol. 30, pp. 613-620, 2012.

[5] Türkiye Çevre Vakfi, Türkiye'nin Çevre Sorunları, Ankara, 2003.

[6] Z. Şen, "Türkiye'nin Temiz Enerji İmkânları," Mimar ve Mühendis Dergisi, vol. 33, pp. 6-12, 2004.

[7] Güneş santrali tarlası. (2012, October). [Online]. Available: http://www.mozturk.net/ güneş santrali tarlası.

[8] PVGIS. Photovoltaic Geographical Information System. (2012, October). [Online]. Available: http://re.jrc.ec.europa.eu/pvgis/.

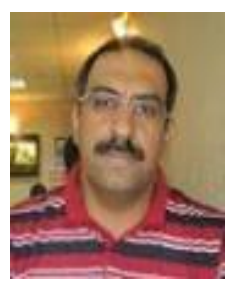

Kemal Akkılıç was born in 1972, Diyarbakır, Turkey. He received the B.S., M.S and Ph.D. degrees from Dicle University, Diyarbakır, Turkey, in 1993, 1997, and 2002, respectively.

From 1993 to 1996 he was a physics teacher in high schools and from 1996 to 2004 he was a research assistant with Dicle University and is currently an assistant professor with Department of Physics Teacher Education. Now he is making efforts to be an associate professor in the same department. He research interests mainly include metal semiconductor contacts, schottky diodes, solar cell structure.

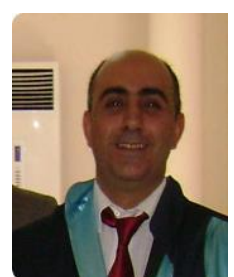

Yusuf Selim Ocak was born in 1976, Diyarbakır, Turkey. He received the B.S., M.S and Ph.D. degrees from Middle East Technical University and Dicle University, Turkey, in 2002, 2006, and 2010, respectively.

From 2002 to 2009 he was a physics teacher in high schools and from 2009 to 2013 he was a research assistant with Dicle University and is currently an assistant professor with Department of Physics Teacher Education. Now he is making efforts to be an associate professor in the same department. He research interests mainly include metal semiconductor contacts, schottky diodes, solar cell structure.

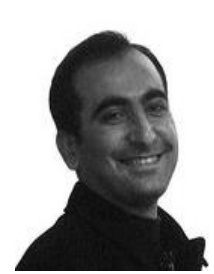

Musa Yılmaz was born in Batman, Turkey in 1979 $\mathrm{He}$ received the B.Sc., M.Sc. and Ph.D. degrees in electrical Edu. and Eng. from Abant İzzet Baysal Unv., Marmara Uni., Turkey, in 2001, 2004 and 2013, respectively. In 2001, he joined the Electrical Dept. of Düzce Tech. Teacher's Training College as a research. During 2003-2004, he has worked at the Energy Minister as an engineer. From 2004 to 2013, he worked at the Elec. Dept. of Dicle University as an instructor and a lecturer. Since 2013, he is working at the Electrical and Energy Dept. of Diyarbakir Technical Science Vocational School of Dicle Uni. as a Dr. His research interests are in the areas of electrical engineering educations, solar energy, solar tracking systems, photovoltaic panels and their controls and design. 



\section{Pollution Control}


